\title{
Factors affecting mortality and reoperations in high-energy pelvic fractures
}

\author{
Peyman Bakhshayesh ${ }^{1}\left[\right.$ D $\cdot$ Lars Weidenhielm $^{1} \cdot$ Anders Enocson $^{1}$
}

Received: 3 January 2018 / Accepted: 5 April 2018 / Published online: 19 April 2018

(c) The Author(s) 2018

\begin{abstract}
Aim Factors affecting mortality during the first year following high-energy pelvic fractures has not been reported previously. Nor has surgical complications leading to reoperations been reported in a cohort with only high-energy pelvic trauma patients. Objectives The aim of this study was to report and analyse factors affecting outcome, in terms of mortality and reoperations, up to 1 year after the injury in patients with a traumatic pelvic ring injury due to a high-energy trauma.

Materials and methods Data from the SweTrau (Swedish National Trauma Registry) on patients admitted to the Trauma Centre Karolinska in Stockholm, Sweden, were collected. Inclusion criteria were adults (age $\geq 18$ ), trauma with a high-energy mechanism, alive on arrival, Swedish personal identification number, reported pelvic fracture on CT scan. Patient records and radiographies were reviewed. The study period was 2011-2015 with 1-year follow-up time. Univariate and regression analysis on factors affecting mortality was performed. Risk of reoperation was analysed using univariate and case-by-case analysis. Results We included 385 cases with mean age $47.5 \pm 20.6$ years ( $38 \%$ females): 317 pelvic fractures, 48 acetabular fractures and 20 combined injuries. Thirty-day mortality was $8 \%$ (30/385), and 1-year mortality was $9 \%(36 / 385)$. The main cause of death at 1 year was traumatic brain injury (14/36) followed by high age ( $>70)$ with extensive comorbidities (8/36). Intentional fall from high altitude (OR 6, CI 2-17), GCS $<8$ (OR 12, CI 5-33) and age $>70$ (OR 17, CI 6-51) were factors predicting mortality. Thirty patients $(22 \%, 30 / 134)$ were further reoperated due to hardware-related $(n=18)$ or non-hardware-related complications $(n=12)$. Hardware-related complications included: mal-placed screws $(n=7)$, mal-placed plate $(n=1)$, implant failure $(n=6)$, or mechanical irritation from the implant $(n=4)$. Non-hardware-related reasons for reoperations were: infection $(n=10)$, skin necrosis $(n=1)$, or THR due to post-traumatic osteoarthritis $(n=1)$.

Conclusion Non-survivors in our study died mainly because of traumatic brain injury or high age with extensive comorbidities. Most of the mortalities occurred early. Intentional injuries and especially intentional falls from high altitude had high mortality rate. Reoperation frequency was high, and several of the hardware-related complications could potentially have been avoided.
\end{abstract}

Keywords Pelvic bone $\cdot$ Intention $\cdot$ Injury severity score $\cdot$ Glasgow coma scale $\cdot$ Orthopaedic surgery $\cdot$ Reoperation . Accidents/mortality

\section{Introduction}

Peyman Bakhshayesh

peyman.bakhshayesh@ki.se

Lars Weidenhielm

lars.weidenhielm@sll.se

Anders Enocson

anders.enocson@sll.se

1 Department of Molecular Medicine and Surgery (MMK), Karolinska Institute, 17176 Stockholm, Sweden
Traumatic pelvic ring injury (TPRI) is a collection name for pelvic and acetabular fractures. The incidence has been reported to be 17-37/100,000 person-years [1-5], and the high-energy TPRIs have a reported incidence of 10/100,000 person-years [1]. TPRIs have historically been considered serious injuries resulting in a mortality rate of $7-47 \%$ in poly-trauma patients [1, 6-11]. Pelvic bleeding has been reported as a major contributor to mortality in these patients [11]. However, during the last decades several authors have found that concomitant injuries such as head or chest injury, 
with or without bleeding, can significantly affect the mortality rather than solely bleeding caused by the pelvic fracture $[12,13]$. Not all of these injuries are caused by non-intentional accidents, but some are actually caused by intentional acts by the patients, a fact that is rarely discussed or analysed in the existing literature. Most of the deaths in poly-trauma patients happen early during the first 30 days, and therefore this parameter has been commonly used in trauma research. Later follow-ups are more difficult to perform, and mortality between 30 days and 1 year has not been reported as an outcome in high-energy poly-trauma patients previously. In the survivor group, an appropriate definitive fixation is of value and reoperation might prolong rehabilitation and return to normal daily activity [14]. Definitive fixation of TPRIs consists of restoration of the pelvic anatomy by means of plates, screws, rods, or external fixators [15-17]. There are several published articles addressing implant-related complications following a single method, such as sacro-iliac (SI) screws, posterior tension band plating, posterior iliolumbar fixation [18-21]. However, there are only a few reports on overall risks for reoperations without in detail description following pelvic or acetabular fracture surgery in an unselected population of high-energy trauma patients [22,23].

\section{Aim}

The aim of this study was to report and analyse factors affecting outcome, in terms of mortality and reoperations, up to 1 year after the injury in patients with a TPRI due to a high-energy trauma.

\section{Materials and methods}

The trauma unit at the Karolinska University Hospital is the primary receiving unit for all high-energy trauma victims in the Stockholm region with a catchment population of around 2.3 million [24]. All patients with a high-energy TPRI admitted as trauma alerts to the Karolinska University Hospital during 2011-2015 were identified via the SweTrau registry. The SweTrau is a Swedish national trauma registry with a coverage of almost $70 \%$ of all poly-trauma patients in the country and $>80 \%$ in the Stockholm's county [25]. Criteria for registration in the SweTrau registry are trauma victims accepted to the trauma units when a trauma alert has been triggered [25]. A TPRI was defined as a bony or ligamentous injury to the pelvic ring (sacrum, coccyx, ischium, pubic bone, or innominate bones including acetabulum). Patient records were searched until 31 December 2016 or death, giving a minimum follow-up time of 1 year.

Initially, a total of 8453 trauma records for the period 2011-2015 were identified. Each trauma case had up to 10 diagnoses based on the ICD 10 (International Classification of Disease) in their records. Patients with diagnoses including S32 and S33 were selected, resulting in 750 patients. Spinal fractures with ICD code S32.00 but without a TPRI were subsequently excluded. This left us with 586 patients whose records were reviewed with respect to the following inclusion criteria:

(1) High-energy injury mechanism, defined as road and traffic-related injuries, high falls, industrial and agricultural injuries [1].

(2) Injury to the pelvic ring on CT scan.

(3) Patients alive on arrival (based on existing vital signs).

(4) Swedish personal ID-number.

(5) Age $\geq 18$ years on admission.

Non-survivors were compared with survivors (control group). (Patients' characteristics are presented in Table 1a.) Surgically treated patients were divided into those who underwent a reoperation and those who did not (control group). (Patients' characteristics are presented in Table 1b.) A reoperation was defined as an unexpected event following primary surgery demanding new surgery during the study period. Cause of death was analysed based on review of the patient records and the death report. High age was defined as age $>70$. Extensive comorbidities were defined as patients with one or more systematic disease. Fracture patterns were analysed and classified using the initial trauma CT scan. Pelvic fractures were classified using the Young-Burgess classification system [26]. Acetabular fractures were classified according to Letournel [27].

\section{Statistics}

The Mann-Whitney $U$ test was used for scale variables in independent groups. Normality was tested with the Shapiro-Wilk test. Nominal variables were tested by the Chi-square test or the Fisher's exact test. All tests were two-sided. Multivariate logistic regression analysis was performed and the results are presented as odds ratio (OR) with confidence interval (CI). The results were considered significant at $p<0.05$. Statistical analysis was performed using IBM SPSS Statistics version 24 for Windows.

\section{Results}

A total of 385 patients ( 145 females) with mean age $( \pm$ SD) $47.5 \pm 20.6$ years fulfilled all the inclusion criteria and were included in the study. The median follow-up time was 40 (IQR 26-56) months. A majority of the patients $(n=251$, $65 \%$ ) were treated non-surgically. For those patients treated surgically, the median time to primary surgery was 3 (IQR 2-5) days. 
Table 1 Type of pelvic fracture in relation to treatment

\begin{tabular}{|c|c|c|c|c|c|c|}
\hline \multirow[t]{2}{*}{ Fracture type } & \multirow[t]{2}{*}{$n=(\%)$} & \multicolumn{5}{|c|}{ Type of treatment $n$} \\
\hline & & Non-surgical & Plating & SI-screw & Ex-fix & Combined \\
\hline All & $317(100)$ & 239 & 18 & 8 & 4 & 48 \\
\hline APC 1 & $5(1.6)$ & 4 & 1 & 0 & 0 & 0 \\
\hline APC 2 & $21(6.6)$ & 3 & 7 & 0 & 2 & 9 \\
\hline APC 3 & $10(3.2)$ & 0 & 1 & 1 & 0 & 8 \\
\hline LC 1 & $183(58)$ & 180 & 2 & 0 & 0 & 1 \\
\hline LC 2 & $13(4.1)$ & 7 & 2 & 3 & 1 & 0 \\
\hline LC 3 & $17(5.4)$ & 4 & 2 & 1 & 1 & 9 \\
\hline Vertical shear & $62(20)$ & 39 & 2 & 3 & 0 & 18 \\
\hline Combined & $6(1.9)$ & 2 & 1 & 0 & 0 & 3 \\
\hline
\end{tabular}

(b) Patients with acetabular fractures (Letournel classification) and type of treatment ${ }^{\mathrm{b}}$

\begin{tabular}{lllll}
\hline Fracture type & $n=(\%)$ & \multicolumn{2}{l}{ Type of treatment $n$} & Plating \\
\cline { 3 - 5 } & & Non-surgical & 33 & 5 \\
\hline All & $48(100)$ & 10 & 16 & 3 \\
Post wall & $23(48)$ & 4 & 0 & 0 \\
Post column & $1(2.1)$ & 1 & 0 & 1 \\
Ant column & $1(2.1)$ & 0 & 0 & 1 \\
Transverse & $2(4.2)$ & 1 & 1 & 0 \\
T-type & $4(8.3)$ & 3 & 5 & 0 \\
Transverse and post wall & $5(10)$ & 0 & 0 & 0 \\
Ant column post hemi-transverse & $0(0)$ & 0 & 1 & 0 \\
Both column & $12(27)$ & 1 & \\
\hline
\end{tabular}

(c) Patients with combined fractures (pelvic and acetabular) and type of treatment

\begin{tabular}{lllll}
\hline Fracture type & $n$ & Type of treatment $n$ & & Plating \\
\cline { 3 - 5 } & & Non-surgical & 12 & 6 \\
\hline Combined mechanism & 20 & 2 & 12 & 6 \\
\hline
\end{tabular}

${ }^{a} A P C$ Antero-posterior compression, $L C$ Lateral compression, Ex-fix External fixation

${ }^{\mathrm{b}}$ Post Posterior, Ant Anterior

Fracture types were: pelvic $(n=317)$, acetabular $(n=48)$, or combined $(n=20)$ (Table $1 \mathrm{a}-\mathrm{c})$. Mean age $( \pm \mathrm{SD})$ was $48.0( \pm 21.1)$ years for patients with pelvic fractures, $46.1( \pm 18.2)$ years for patients with acetabular fractures, and $44.5( \pm 16.7)$ years for patients with combined fractures. There was a greater proportion of females among patients with pelvic fractures $(131 / 317,41 \%)$ compared to patients with acetabular fractures $(9 / 48,19 \%)$ $(p=0.002)$, and 38 out of $48(79 \%)$ acetabular fractures were operated in comparison with 78 out of 317 (25\%) pelvic fractures $(p<0.001)$.

\section{Mortality}

The overall 30-day mortality was 30/385 (7.8\%) and the 1-year mortality was $36 / 385$ (9.4\%) (Table 2). A fall from high altitude was the injury mechanism in 19 out of 30 cases of 30-day mortality, and in 24 out of 36 cases of 1-year mortality. Mortality in the first 30 days was caused by: traumatic brain injury $(n=13)$, high age ( $>70$ years) with extensive comorbidities $(n=6)$, traumatic chest injury $(n=4)$, pelvic bleeding $(n=4)$, abdominal bleeding $(n=2)$, or chest bleeding $(n=1)$. All cases of bleeding leading to death died during the first $24 \mathrm{~h}$. The cause of death for those six patients 
Table 2 Comparison between survivors and non-survivors

\begin{tabular}{|c|c|c|c|c|c|}
\hline & & All patients $n=385$ & $\begin{array}{l}\text { Survivors } \\
1 \text {-year } \\
n=355\end{array}$ & Non-survivors $n=36$ & $p$ value \\
\hline Age & Mean \pm SD & $47 \pm 21$ & $46 \pm 19$ & $63 \pm 26$ & $<0.001$ \\
\hline \multicolumn{6}{|l|}{ Gender } \\
\hline Female & $n(\%)$ & $145(38)$ & $129(37)$ & $16(44)$ & \multirow[t]{2}{*}{0.37} \\
\hline Male & $n(\%)$ & $240(62)$ & $220(63)$ & $20(56)$ & \\
\hline \multicolumn{6}{|l|}{ Fracture type } \\
\hline Pelvic & $n(\%)$ & $317(83)$ & $286(82)$ & $31(86)$ & \multirow[t]{3}{*}{0.939} \\
\hline Acetabular & $n(\%)$ & $48(12)$ & $44(13)$ & $4(11)$ & \\
\hline Combined & $n(\%)$ & $20(5)$ & $19(5)$ & $1(3)$ & \\
\hline \multicolumn{6}{|l|}{ Mechanism of injury } \\
\hline MVA & $n(\%)$ & $194(50)$ & $182(52)$ & $12(33)$ & \multirow[t]{3}{*}{0.001} \\
\hline Fall & $n(\%)$ & $154(40)$ & $130(37)$ & $24(67)$ & \\
\hline Others & $n(\%)$ & $37(10)$ & $37(11)$ & $0(0)$ & \\
\hline \multicolumn{6}{|l|}{ Cause of injury } \\
\hline Intentional & $n(\%)$ & $92(24)$ & $78(22)$ & $14(40)$ & \multirow[t]{2}{*}{0.035} \\
\hline Non-intentional & $n(\%)$ & $292(76)$ & $271(78)$ & $21(60)$ & \\
\hline ISS & Median (IQR) & $22(14-38)$ & $22(13-35)$ & $33(17-50)$ & 0.011 \\
\hline GCS & Median (IQR) & $13(13-15)$ & $13(13-15)$ & $8(3-14)$ & $<0.001$ \\
\hline Systolic BP & Mean \pm SD & $121 \pm 28$ & $121 \pm 28$ & $114 \pm 31$ & 0.219 \\
\hline Respiratory rate & Mean \pm SD & $21 \pm 8$ & $20 \pm 7$ & $26 \pm 10$ & $<0.001$ \\
\hline Pulse rate & Mean \pm SD & $90 \pm 19$ & $90 \pm 19$ & $91 \pm 18$ & 0.895 \\
\hline Head \& neck injury & $n(\%)$ & $118(31)$ & $99(28)$ & $19(54)$ & 0.003 \\
\hline Chest injury & $n(\%)$ & $168(44)$ & $150(43)$ & $18(50)$ & 0.481 \\
\hline Abdominal injury & $n(\%)$ & 74 (19) & $68(19)$ & $6(17)$ & 0.826 \\
\hline
\end{tabular}

MVA All type of motor vehicle accidents, ISS Injury Severity Score, GCS Glasgow Coma Scale Score, $B P$ Blood Pressure, H\&N Injury Head and Neck Injury who died later than 30 days during the first year were: sepsis with multi-organ failure $(n=3)$, high age $(>70$ years) with extensive comorbidities $(n=2)$, or late sequelae from a traumatic brain injury $(n=1)$. Surgically treated patients had lower 30 -day mortality $(2 / 134,1.5 \%)$ compared to nonsurgically treated patients $(28 / 251,11 \%)(p<0.001)$. As was the 1-year mortality lower among surgically treated (4/134, $3.0 \%)$ compared to non-surgically treated patients $(32 / 251$, $13 \%)(p=0.001)$.

\section{Intentional versus non-intentional cause of injury}

There was an increased 30-day mortality among patients with intentional $(14 / 92,15 \%)$ compared to non-intentional $(16 / 293,5.5 \%)$ cause of injury $(p=0.006)$. There was also an increased 1-year mortality among patients with intentional (14/92, 15\%) compared to non-intentional (22/293, $7.5 \%$ ) cause of injury ( $p=0.04)$, as no further fatalities happened in intentional group between 30 days and 1 year. Intentional trauma patients displayed higher ISS (median, IQR) $(34,22-43)$ compared to non-intentional patients $(20,12-33)(p<0.001)$, and they had a greater proportion of fall from high altitude $(76 / 92,83 \%)$ compared to nonintentional patients $(78 / 293,27 \%)(p<0.001)$ (Table 3$)$. Regression analysis including factors affecting mortality was conducted. Based on 36 cases of fatalities up to 1 year, three factors were selected to predict a mortality model. We found that mechanism of injury and injury reason were confounding each other. A model based on intentional versus non-intentional (OR 4, CI 1.5-11.5), Glasgow Coma Scale $($ GCS $) \leq 8$ (OR 11, CI 4-30), age $\geq 70$ (OR 21, CI 7-61) showed an appropriate goodness of fit using Hosmer-Lemeshow test $(p=1.0)$. Nagelkerke $R^{2}$ was 0.4 . Another model using Mechanism of injury showed that fall from high altitude (fall) compared to motor vehicle accident (MVA) (OR 3.5, CI 1.4-9), GCS $\leq 8$ (OR 14, CI 5-37), and age $\geq 70$ (OR 13, CI 5-33) had reliable goodness of fit with Hosmer-Lemeshow test $(p=0.9)$ and comparable Nagelkerke $R^{2}, 0.4$. A combination of Injury reason and mechanism of injury in a regression model was thus more appropriate. In this final model, intentional fall compared to non-intentional MVA had OR 6 (CI 2-17), GCS $\leq 8$ OR 12 (CI 5-33), and age $\geq 70$ OR 17 (CI 6-51). Hosmer-Lemshow goodness of fit test had a $p$ 
Table 3 Comparison between patients with Intentional and Non-intentional injuries

\begin{tabular}{lllllr}
\hline & & All & Intentional & Non-Intentional & $p$ value \\
\hline Age & Mean \pm SD & $47 \pm 21$ & $40 \pm 16$ & $50 \pm 21$ & $<0.001$ \\
Female & $n(\%)$ & $145(38)$ & $38(41)$ & $107(37)$ & 0.421 \\
Pelvic & $n(\%)$ & $316(82)$ & $79(86)$ & $237(81)$ & 0.067 \\
Acetabulum & & $48(13)$ & $6(6)$ & $42(14)$ & \\
Both & & $20(5)$ & $7(8)$ & $13(5)$ & \\
Mechanism & $n(\%)$ & & & & \\
MVA & & $194(50)$ & $15(16)$ & $179(61)$ & \\
Fall & & $153(40)$ & $76(83)$ & $77(26)$ & $<0.001$ \\
Others & $37(7)$ & $1(0)$ & $36(10)$ & $<0.001$ \\
ISS & Median (IQR) & $22(14-38)$ & $34(22-43)$ & $20(14-38)$ & 0.302 \\
GCS & Median (IQR) & $15(13-15)$ & $14(8-15)$ & $15(14-15)$ & 0.022 \\
H\&N injury & $n(\%)$ & $118(29)$ & $32(35)$ & $86(29)$ & 0.069 \\
Chest injury & $n(\%)$ & $168(44)$ & $50(54)$ & $118(40)$ & $<0.001$ \\
Abdominal injury & $n(\%)$ & $74(19)$ & $24(26)$ & $50(17)$ & $<0.001$ \\
HLOS & Median (IQR) & $10(5-23)$ & $16(10-36)$ & $9(5-20)$ & 0.38 \\
ICULOS & Median (IQR) & $1(0-5)$ & $2(0-9)$ & $0(0-4)$ & 0.006 \\
ORIF & $n(\%)$ & $134(35)$ & $36(39)$ & $98(34)$ & 0.035 \\
30-day mortality & $n(\%)$ & $30(8)$ & $14(15)$ & $16(5.5)$ & 0.18 \\
1-year mortality & $n(\%)$ & $35(9)$ & $14(15)$ & $21(7)$ & $5(1-26)$ \\
Time to death & Median (IQR) & $4.5(1-15)$ & $1.5(1-9)$ & & \\
\hline
\end{tabular}

MVA All type of motor vehicle accidents, ISS Injury Severity Score, GCS Glasgow Coma Score, $H \& N$ Injury Head and Neck Injury, HOLS Hospital Length of Stay, ICULOS Intensive Care Unit Length of Stay, ORIF Open Reduction and Internal Fixation value $=0.9$ and Nagelkerke $R^{2}$ was 0.4. ISS as a scale variable $(p=0.3)$ or ISS $>16(p=0.9)$ or ISS $>25(p=0.5) \mathrm{did}$ not remain significant in a multivariate analysis.

\section{Reoperations}

Thirty out of $134(22 \%)$ surgically treated patients were reoperated (Table 4). The reasons for reoperations were hardware-related complications in 18 patients and nonhardware-related complications in 12 patients. Hardwarerelated complications included: mal-placed screws $(n=7)$, mal-placed plate $(n=1)$, implant failure $(n=6)$, or mechanical irritation from the implant $(n=4)$. Non-hardware-related reasons for reoperations were: infection $(n=10)$, skin necrosis $(n=1)$, or total hip replacement (THR) due to post-traumatic osteoarthritis despite an adequate fixation $(n=1)$.

The eight patients with mal-placed implants consisted of three patients with SI-screws, of which 1 SI-screw penetrated to the ipsilateral S1 root, $1 \mathrm{SI}$-screw penetrated the contralateral sacral wall inducing L5-root symptom and the third case was bilateral SI-screws causing anterior displacement of the sacral body causing L5-S1 symptoms (Figs. 1, $2,3)$. In addition, there were three cases of screw penetration to the hip joint following anterior column fixation of acetabular fractures, whereof 2 were found early on the postoperative CT scans, and 1 was found during THR surgery
2.5 years later. Finally, there was 1 case with 2 SI-screws who needed screw tightening. The last case of mal-placed implant was an anterior SI-joint plate placed too medial and thereby causing local L5-root symptom. Implant failure occurred in six cases: 3 posterior wall acetabular fractures with loss of reduction, 2 anterior symphyseal plates with loss of reduction and 1 plated trans iliac wing fracture with loss of reduction. Details on patients reoperated due to hardwarerelated problems are given in Table 5. The median (IQR) hospital length of stay was 23 (10-44) days for patients who underwent a reoperation during their primary hospital stay, compared to 18 (10-25) for surgically treated patients who were not reoperated $(p=0.2)$.

\section{Discussion}

The main finding of this study was that the overall mortality was relatively low, but for a subgroup of patients, those with an intentional trauma mechanism and fall from high altitude, the mortality was severely elevated. Regression analysis revealed that intentional injuries (particularly intentional falls) and GCS $<8$ and high age $(>70)$ were predictors of mortality. Traumatic brain injury was the main cause of mortality. The reoperation rate was considerable, and several of the reoperations could possibly have been avoided. 
Table 4 Comparison of characteristic factors in reoperated and non-reoperated patients

\begin{tabular}{|c|c|c|c|c|c|}
\hline & & $\begin{array}{l}\text { All surgically } \\
\text { treated } n=134 \\
(100 \%)\end{array}$ & $\begin{array}{l}\text { No reoperation } \\
n=104(78 \%)\end{array}$ & $\begin{array}{l}\text { Reoperation } \\
n=30(22 \%)\end{array}$ & $p$ value \\
\hline Age & Mean \pm SD & $45 \pm 16$ & $45 \pm 16$ & $45 \pm 15$ & 0.875 \\
\hline \multicolumn{6}{|l|}{ Gender } \\
\hline Female & $n(\%)$ & $37(28)$ & $29(28)$ & $8(27)$ & \multirow[t]{2}{*}{1.0} \\
\hline Male & $n(\%)$ & $97(72)$ & $75(72)$ & $22(73)$ & \\
\hline \multicolumn{6}{|l|}{ Fracture type } \\
\hline Pelvic & $n(\%)$ & $78(58)$ & $58(56)$ & $20(67)$ & \multirow[t]{3}{*}{0.635} \\
\hline Acetabular & $n(\%)$ & $38(28)$ & $31(30)$ & $7(23)$ & \\
\hline Combined & $n(\%)$ & $18(14)$ & $15(14)$ & $3(10)$ & \\
\hline \multicolumn{6}{|l|}{ Mechanism of injury } \\
\hline MVA & $n(\%)$ & $77(58)$ & $60(58)$ & $17(56)$ & \multirow[t]{3}{*}{0.14} \\
\hline Fall & $n(\%)$ & $46(34)$ & $38(36)$ & $8(27)$ & \\
\hline Others & $n(\%)$ & $11(8)$ & $6(6)$ & $5(17)$ & \\
\hline \multicolumn{6}{|l|}{ Cause of injury } \\
\hline Intentional & $n(\%)$ & $36(27)$ & $29(28)$ & $7(23)$ & \multirow[t]{2}{*}{0.815} \\
\hline Non-intentional & $n(\%)$ & $98(73)$ & $75(72)$ & $23(77)$ & \\
\hline ISS & Median (IQR) & $29(17-42)$ & $29(17-41)$ & $30(19-42)$ & 0.837 \\
\hline GCS & Median (IQR) & $15(13-15)$ & $15(13-15)$ & $15(14-15)$ & 0.407 \\
\hline Systolic BP & Mean \pm SD & $118 \pm 30$ & $120 \pm 30$ & $115 \pm 29$ & 0.536 \\
\hline Respiratory rate & Mean \pm SD & $21 \pm 8$ & $21 \pm 7$ & $23 \pm 11$ & 0.406 \\
\hline Heart rate & Mean \pm SD & $92 \pm 19$ & $92 \pm 20$ & $91 \pm 19$ & 0.783 \\
\hline $\mathrm{H} \& \mathrm{~N}$ injury & $n(\%)$ & $28(21)$ & $24(23)$ & $4(13)$ & 0.314 \\
\hline Chest injury & $n(\%)$ & $63(47)$ & $50(48)$ & $13(43)$ & 0.683 \\
\hline Abdominal injury & $n(\%)$ & $34(25)$ & $26(25)$ & $8(27)$ & 0.817 \\
\hline Time to first surgery & Median (IQR) & $3(2-5)$ & $3(2-5)$ & $3(2-5)$ & 0.629 \\
\hline BMI & Median (IQR) & $25(22-29)$ & $25(22-29)$ & $24(22-31)$ & 0.846 \\
\hline HLOS & Median (IQR) & $18(10-27)$ & $18(10-25)$ & $23(10-44)$ & 0.282 \\
\hline ICULOS & Median (IQR) & $2(0-10)$ & $2(0-10)$ & $1(1-14)$ & 0.485 \\
\hline Mortality 30 day & $n(\%)$ & $2(1.5)$ & $2(2)$ & $0(0)$ & 1.0 \\
\hline Mortality 1 year & $n(\%)$ & $4(3)$ & $3(3)$ & $1(3)$ & 1.0 \\
\hline
\end{tabular}

MVA All type of motor vehicle accidents, ISS Injury Severity Score, GCS Glasgow Coma Score, $H \& N$ Injury Head and Neck Injury, HOLS Hospital Length of Stay, ICULOS Intensive Care Unit Length of Stay, ORIF Open Reduction and Internal Fixation

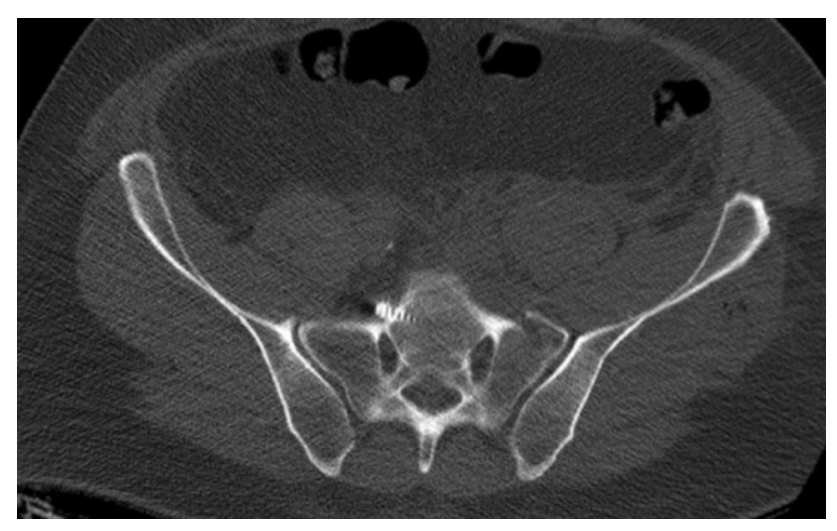

Fig. 1 Anterior penetration of contralateral anterior sacral wall with L5-root palsy

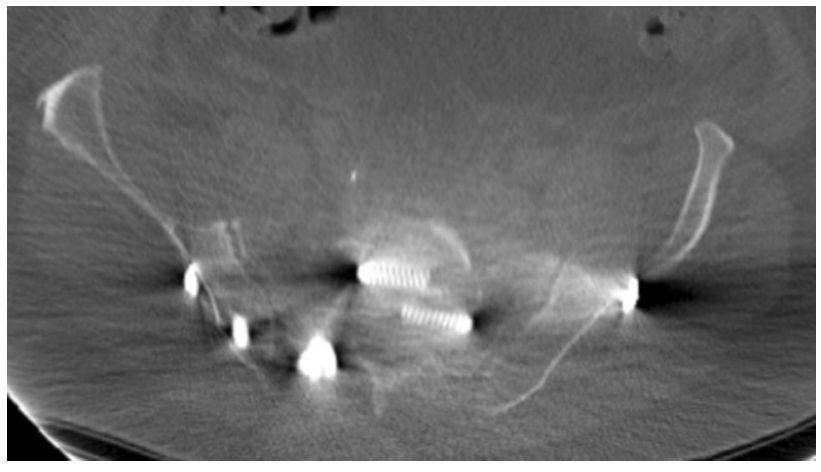

Fig. 2 Penetration of posterior SI-screw in the S1-canal

\section{Epidemiology}

The incidence of pelvic fractures in our study was 


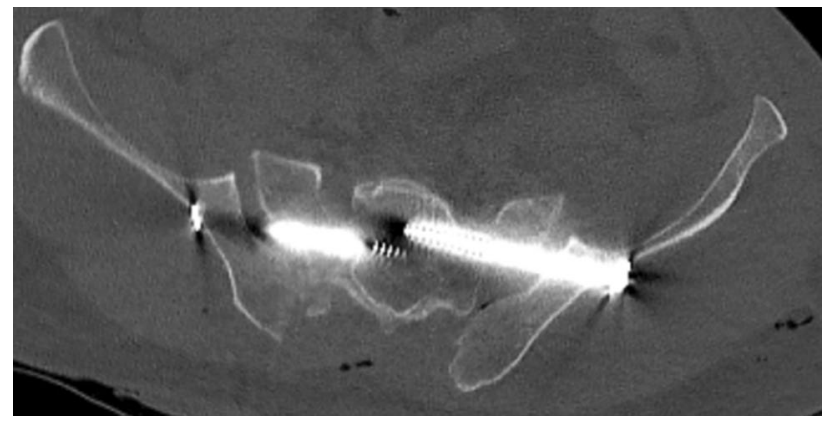

Fig. 3 Anterior sacral dislocation and insertion of bilateral SI-screws causing nerve palsies

comparably lower, estimated to $3.6 / 100,000$ person-years, than the previously reported incidence of high-energy pelvic trauma of 10/100,000 person-years, and this may be due to a lower incidence of motor vehicle accidents [1]. Pelvic fractures were more common than acetabular fractures in our material, and this is in agreement with other reports $[8,28]$. Pelvic fractures were proportionally more common among women, a finding that has been reported by others $[1,3]$. Fall injuries were more common (40\%) compared to previous published data (5-36\%) [1, 9, 16, 29]. However, our results were comparable to epidemiological findings in Finland by Lüthje et al. [3] who reported 51\% fall injuries. The high proportion of fall in our cohort can be explained by the fact that other causes, such as traffic accidents, were less common in our material compared to other reports $[1,29,30]$.

\section{Mortality}

Our overall 30-day mortality rate was low (8\%) compared to most other reports $(7-47 \%)[1,6-8,10,11]$. Furthermore, the mortality rate increased with only $1 \%$ between 30 days and 1 year. To our knowledge, this has not been reported previously. The most common cause of death was not bleeding associated with the pelvic injury, but a traumatic brain injury. Our results might reflect the fact that substantial numbers of our cohort were intentionally injured patients (24\%) and a fall from high altitude was a common trauma mechanism (40\%). Sweden is relatively safe country with respect to traffic injuries, and the fact that head injuries or GCS $<8$, age $>70$ and intentional falls were predictors of mortality in our study might only give information about our population of study, and our results should primarily be compared with data from similar trauma populations.

\section{Intentional versus non-intentional cause of injury}

We found an increased rate of 30-day, as well as 1-year, mortality for those with an intentional trauma mechanism compared to for the non-intentional cases. This could be due to several reasons. Deaths related to traumatic head injuries among cases with intentional injuries in our material could be related to more cases landing on their heads compared to Gabbe et al. [31], while their higher mortality rate (48\%) could be explained by more severely injured cases as they included only cases with ISS $>16$, while we included cases based on the mechanism of injury (high-energy trauma). However, we were not able to show any effect of ISS as a predictor of mortality in our study.

\section{Reoperations}

One hundred and thirty-five of the 385 patients were operated, and of those 30 patients were reoperated. The reasons were mainly hardware-related complications or infections. Unfortunately, there are only few reports regarding overall reoperation frequency of high-energy TPRI patients. We consider our overall reoperation rate as high, but it is in level with other reports [14, 22]. Several of our implant complications consisted of mal-placed implants $(n=8)$ or implant failures $(n=6)$. With better preoperative planning and better intra-operative imaging techniques, we think that the majority of these reoperations might have been avoidable. In our cohort 24 cases with "posterior wall" and "transverse and posterior wall" were operated. Of those, we had three cases of implant failure. All suffered from multi-fragmentation of the posterior wall, a fact that previously been highlighted by Saterbak et al. [21] who in a retrospective study of 42 cases with posterior wall acetabular fractures reported $26 \%$ implant failure with loss of reduction. In their series multifragmentation of the posterior wall and fractures into the subchondral arc was reported as predictors for reoperation. Two cases of 22 with anterior symphyseal plate in our series underwent reoperation because of failure. Morris et al. [32] in a retrospective study of 148 cases with anterior symphyseal plates reported $42 \%$ implant failure, but the majority of these failures were asymptomatic.

\section{Strengths and limitations}

One strength of our study was that no case was lost to follow-up. This was because of linkage between Swedish Population Registry and the hospital's patient record system which made it possible to report 1-year mortality. Another strength of our study is the unique Swedish personal identification number which enabled us to follow all the cases in different data systems such as patient records, radiology data system. Our study had some clear limitations. Its retrospective design and lack of pre-designed control groups were some of our limitations. Another weakness of our study was the heterogeneous trauma panorama of the patients. 
Table 5 Hardware related complications in 18 patients

\begin{tabular}{|c|c|c|c|c|c|c|c|}
\hline No & Gender & Age & Fracture type & Type of primary surgery & Indication for reoperation & Time to reoperation & Type of reoperation \\
\hline 1 & Male & 67 & $\begin{array}{l}\text { Acetabulum } \\
\text { Transverse-post wall }\end{array}$ & Post wall plate & $\begin{array}{l}\text { Implant failure } \\
\text { Loss of reduction and hip } \\
\text { dislocation }\end{array}$ & 23 days & Replating \\
\hline 2 & Male & 45 & $\begin{array}{l}\text { Acetabulum } \\
\text { Post wall }\end{array}$ & Post wall plate & $\begin{array}{l}\text { Implant failure } \\
\text { Hip dislocation and signs } \\
\text { of OA }\end{array}$ & 47 days & THR \\
\hline 3 & Male & 20 & $\begin{array}{l}\text { Pelvic } \\
\text { LC } 3\end{array}$ & $\begin{array}{l}\text { SI-screw and iliac wing } \\
\text { plate }\end{array}$ & $\begin{array}{l}\text { Implant failure } \\
\text { Fracture dislocation of } \\
\text { right iliac wing (Insuf- } \\
\text { ficient fixation) }\end{array}$ & 19 days & Replating \\
\hline 4 & Male & 46 & $\begin{array}{l}\text { Acetabulum } \\
\text { Post wall }\end{array}$ & Post wall plate & $\begin{array}{l}\text { Implant failure } \\
\text { Loss of reduction }\end{array}$ & 5 days & Replating \\
\hline 5 & Male & 59 & $\begin{array}{l}\text { Pelvic } \\
\text { LC } 2\end{array}$ & Anterior symphyseal plate & $\begin{array}{l}\text { Implant failure } \\
\text { Anteriorly and loss of } \\
\text { reduction }\end{array}$ & 46 days & Screw removal \\
\hline 6 & Female & 49 & $\begin{array}{l}\text { Pelvic } \\
\text { LC } 3\end{array}$ & $\begin{array}{l}\text { SI-screw and symphyseal } \\
\text { plate }\end{array}$ & 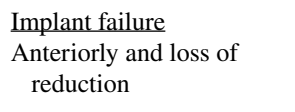 & 15 days & Replating \\
\hline 7 & Male & 28 & $\begin{array}{l}\text { Pelvic } \\
\text { LC } 3\end{array}$ & SI-screws (S1 and S2) & $\begin{array}{l}\text { Mechanical irritation } \\
\text { Locally related to SI- } \\
\text { screws }\end{array}$ & 2 years & SI-screws removal \\
\hline 8 & Male & 61 & $\begin{array}{l}\text { VS fracture and symphy- } \\
\text { seal widening }\end{array}$ & Iliolumbar instrumentation & $\begin{array}{l}\text { Mechanical irritation } \\
\text { Loss of reduction and } \\
\text { prominent iliac screws }\end{array}$ & 3 years & Post tension band removal \\
\hline 9 & Male & 54 & $\begin{array}{l}\mathrm{CM} \text { (Bilateral acetabulum, } \\
\text { post wall), VS pelvic } \\
\text { fracture }\end{array}$ & $\begin{array}{l}\text { Iliolumbar instrumentation } \\
\text { and post wall acetabular } \\
\text { plates }\end{array}$ & $\begin{array}{l}\text { Mechanical irritation } \\
\text { Prominent iliac screws }\end{array}$ & 1.5 years & Post tension band removal \\
\hline 10 & Male & 46 & $\begin{array}{l}\text { Pelvic } \\
\text { LC } 3\end{array}$ & $\begin{array}{l}2 \text { anterior SI-plates, } 1 \text { iliac } \\
\text { wing plate, } 1 \text { anterior lag } \\
\text { screw }\end{array}$ & $\begin{array}{l}\text { Mechanical irritation } \\
\text { Single lag screw }\end{array}$ & 3 years & Lag screw removal \\
\hline 11 & Male & 49 & $\mathrm{CM}$ & $\begin{array}{l}\text { Bilateral SI-screws, Iliol- } \\
\text { umbar instrumentation } \\
\text { and anterior plate }\end{array}$ & $\begin{array}{l}\frac{\text { Mal-placed SI-screw }}{\text { Lt SI-screw disturbed }} \\
\text { S1-root }\end{array}$ & 6 days & SI-screw, reinsertion \\
\hline 12 & Male & 51 & $\begin{array}{l}\text { Pelvic } \\
\text { APC } 3\end{array}$ & $\begin{array}{l}\text { Bilateral SI-screws and } \\
\text { anterior lag screws }\end{array}$ & $\begin{array}{l}\frac{\text { Mal-placed SI-screw }}{\text { Lt SI-screw disturbed }} \\
\text { L5-S1 roots }\end{array}$ & 8 days & $\begin{array}{l}\text { SI-screw changed to ant } \\
\text { SI-plates }\end{array}$ \\
\hline 13 & Male & 46 & $\begin{array}{l}\text { Pelvic } \\
\text { LC } 2\end{array}$ & SI-screw & $\begin{array}{l}\text { Mal-placed SI-screw } \\
\text { Anterior sacral wall } \\
\text { penetration and L-5 root } \\
\text { symptom }\end{array}$ & 2 days & SI-screw reinsertion \\
\hline 14 & Female & 46 & $\begin{array}{l}\text { Pelvic } \\
\text { LC } 3\end{array}$ & $\begin{array}{l}\text { Iliac wing plate, sym- } \\
\text { physeal plate and, } 2 \\
\text { SI-screws }\end{array}$ & $\begin{array}{l}\text { Mal-placed SI-screw } \\
\text { SI-screws needed further } \\
\text { tightening }\end{array}$ & 2 days & SI-screw reinsertion \\
\hline 15 & Female & 62 & $\begin{array}{l}\text { Pelvic } \\
\text { LC } 3\end{array}$ & $\begin{array}{l}\text { SI-screw, SI-plates and } \\
\text { symphyseal plate }\end{array}$ & $\frac{\text { Mal-placed SI-plate }}{\text { Irritating L5-roots }}$ & 6 month & $\begin{array}{l}\text { SI-plates removal and SI- } \\
\text { screw insertion }\end{array}$ \\
\hline 16 & Male & 23 & $\begin{array}{l}\mathrm{CM} \text { including double col- } \\
\text { umn acetabular fracture }\end{array}$ & $\begin{array}{l}\text { Iliac wing plate and post } \\
\text { wall plate }\end{array}$ & $\frac{\text { Screw penetration to }}{\text { acetabulum }}$ & 6 days & $\begin{array}{l}\text { Reinsertion of mal-placed } \\
\text { screw }\end{array}$ \\
\hline 17 & Male & 28 & $\begin{array}{l}\text { Acetabulum } \\
\text { Both column }\end{array}$ & $\begin{array}{l}\text { Iliac wing plates and sepa- } \\
\text { rate post column screws }\end{array}$ & $\frac{\text { Screw penetration to }}{\text { acetabulum }}$ & 3 days & $\begin{array}{l}\text { Reinsertion of mal-placed } \\
\text { screw }\end{array}$ \\
\hline 18 & Male & 26 & $\begin{array}{l}\text { CM, including double col- } \\
\text { umn acetabular fracture }\end{array}$ & $\begin{array}{l}\text { Iliac wing plates and sepa- } \\
\text { rate lag screws }\end{array}$ & $\frac{\text { Screw penetration to }}{\text { acetabulum }}$ & 2.5 years & THR \\
\hline
\end{tabular}

$L C$ Lateral Compression (Young-Burgess classification), APC Antero-Posterior Compression (Young-Burgess classification), $C M$ Combined Mechanism, THR Total Hip Replacement

\section{Conclusion}

Non-survivors in our study died mainly because of traumatic brain injury, or high age with extensive comorbidities. Most of the mortalities occurred early. Intentional injuries and especially intentional falls had high mortality rate in our study. Reoperation frequency was high but in the level with previous reports. A majority of the hardware-related complications could potentially have been avoided. 


\section{Compliance with ethical standards}

Conflict of interest The authors declare that they have no conflict of interest.

Ethical approval The study was performed according to the Declaration of Helsinki and approved by the Local Ethics Committee (DNR: 2016/383-31/4).

Open Access This article is distributed under the terms of the Creative Commons Attribution 4.0 International License (http://creativeco mmons.org/licenses/by/4.0/), which permits unrestricted use, distribution, and reproduction in any medium, provided you give appropriate credit to the original author(s) and the source, provide a link to the Creative Commons license, and indicate if changes were made.

\section{References}

1. Balogh Z, King KL, Mackay P, McDougall D, Mackenzie S, Evans JA, Lyons T, Deane SA (2007) The epidemiology of pelvic ring fractures: a population-based study. J Trauma 63:1066-1073. https ://doi.org/10.1097/ta.0b013e3181589fa4 (discussion 1072-1063)

2. Court-Brown CM, Caesar B (2006) Epidemiology of adult fractures: a review. Injury 37:691-697. https://doi.org/10.1016/j.injur y.2006.04.130

3. Luthje P, Nurmi I, Kataja M, Heliovaara M, Santavirta S (1995) Incidence of pelvic fractures in Finland in 1988. Acta Orthop Scand 66:245-248

4. Melton LJ 3rd, Sampson JM, Morrey BF, Ilstrup DM (1981) Epidemiologic features of pelvic fractures. Clin Orthop Relat Res 155:43-47

5. Ragnarsson B, Jacobsson B (2009) Epidemiology of pelvic fractures in a Swedish county. Acta Orthop Scand 63:297-300. https://doi. org/10.3109/17453679209154786

6. Cheng M, Cheung MT, Lee KY, Lee KB, Chan SC, Wu AC, Chow YF, Chang AM, Ho HF, Yau KK (2015) Improvement in institutional protocols leads to decreased mortality in patients with haemodynamically unstable pelvic fractures. Emerg Med J 32:214-220. https://doi.org/10.1136/emermed-2012-202009

7. Fitzgerald CA, Morse BC, Dente CJ (2014) Pelvic ring fractures: has mortality improved following the implementation of damage control resuscitation? Am J Surg 208:1083-1090. https://doi.org/10.1016/j. amjsurg.2014.09.002 (discussion 1089-1090)

8. Morshed S, Knops S, Jurkovich GJ, Wang J, MacKenzie E, Rivara FP (2015) The impact of trauma-center care on mortality and function following pelvic ring and acetabular injuries. J Bone Joint Surg Am 97:265-272. https://doi.org/10.2106/jbjs.n.00008

9. Sharpe JP, Magnotti LJ, Gobbell WC, Huang X, Perez EA, Fabian TC, Croce MA (2017) Impact of early operative pelvic fixation on long-term self-reported outcome following severe pelvic fracture. J Trauma Acute Care Surg 82:444-450. https://doi.org/10.1097/ ta.0000000000001346

10. Wang H, Robinson RD, Moore B, Kirk AJ, Phillips JL, Umejiego J, Chukwuma J, Miller T, Hassani D, Zenarosa NR (2016) Predictors of early versus late mortality in pelvic trauma patients. Scand J Trauma Resusc Emerg Med 24:27. https://doi.org/10.1186/s1304 9-016-0220-9

11. Verbeek DO, Sugrue M, Balogh Z, Cass D, Civil I, Harris I, Kossmann T, Leibman S, Malka V, Pohl A, Rao S, Richardson M, Schuetz M, Ursic C, Wills V (2008) Acute management of hemodynamically unstable pelvic trauma patients: time for a change? Multicenter review of recent practice. World J Surg 32:1874-1882. https://doi.org/10.1007/s00268-008-9591-z
12. Demetriades D, Martin M, Salim A, Rhee P, Brown C, Chan L (2005) The effect of trauma center designation and trauma volume on outcome in specific severe injuries. Trans Meet Am Surg Assoc 123:206-213. https://doi.org/10.1097/01.sla.0000184169.73614.09

13. Papadopoulos IN, Kanakaris N, Bonovas S, Triantafillidis A, Garnavos C, Voros D, Leukidis C (2006) Auditing 655 fatalities with pelvic fractures by autopsy as a basis to evaluate trauma care. J Am Coll Surg 203:30-43. https://doi.org/10.1016/j.jamcollsurg.2006.03.017

14. Gabbe BJ, Hofstee DJ, Esser M, Bucknill A, Russ MK, Cameron PA, Handley C, de Steiger RN (2015) Functional and return to work outcomes following major trauma involving severe pelvic ring fracture. ANZ J Surg 85:749-754. https://doi.org/10.1111/ans.12700

15. Mears DC, Rubash HE (1984) External and internal fixation of the pelvic ring. Instr Course Lect 33:144-158

16. Pohlemann T, Bosch U, Gansslen A, Tscherne H (1994) The Hannover experience in management of pelvic fractures. Clin Orthop Relat Res 305:69-80

17. Tscherne H, Pohlemann T (1991) [Modern techniques in pelvic fractures including acetabulum fractures]. Langenbecks Archiv fur Chirurgie Supplement Kongressband Deutsche Gesellschaft fur Chirurgie Kongress, 491-496

18. Bellabarba C, Schildhauer TA, Vaccaro AR, Chapman JR (2006) Complications associated with surgical stabilization of high-grade sacral fracture dislocations with spino-pelvic instability. Spine 31:S80-S88. https://doi.org/10.1097/01.brs.0000217949.31762.be (discussion S104)

19. Krappinger D, Larndorfer R, Struve P, Rosenberger R, Arora R, Blauth M (2007) Minimally invasive transiliac plate osteosynthesis for type $\mathrm{C}$ injuries of the pelvic ring: a clinical and radiological follow-up. J Orthop Trauma 21:595-602. https://doi.org/10.1097/ BOT.0b013e318158abcf

20. Routt ML Jr, Simonian PT, Mills WJ (1997) Iliosacral screw fixation: early complications of the percutaneous technique. J Orthop Trauma 11:584-589

21. Saterbak AM, Marsh JL, Nepola JV, Brandser EA, Turbett T (2000) Clinical failure after posterior wall acetabular fractures: the influence of initial fracture patterns. J Orthop Trauma 14:230-237

22. Pavelka T, Salasek M, Weisova D (2013) Complications associated with surgical treatment of pelvic ring fractures. Acta Chir Orthop Traumatol Cechoslov 80:208-215

23. Pohlemann T, Gansslen A, Schellwald O, Culemann U, Tscherne H (1996) Outcome after pelvic ring injuries. Injury 27(Suppl 2):B31-B38

24. (12/04/2017) http://www.scb.se/hitta-statistik/statistik-efter-amne/ befolkning/befolkningens-sammansattning/befolkningsstatistik/

25. SweTrau (2017) In., http://rcsyd.se/anslutna-register/swetraureg

26. Burgess AR, Eastridge BJ, Young JW, Ellison TS, Ellison PS Jr, Poka A, Bathon GH, Brumback RJ (1990) Pelvic ring disruptions: effective classification system and treatment protocols. J Trauma 30:848-856

27. Em Letournel, Judet R, Elson R (1993) Fractures of the acetabulum. Springer-Verlag, New York

28. Pohlemann T, Stengel D, Tosounidis G, Reilmann H, Stuby F, Stöckle U, Seekamp A, Schmal H, Thannheimer A, Holmenschlager F, Gänsslen A, Rommens PM, Fuchs T, Baumgärtel F, Marintschev I, Krischak G, Wunder S, Tscherne H, Culemann U (2011) Survival trends and predictors of mortality in severe pelvic trauma: estimates from the German Pelvic Trauma Registry Initiative. Injury 42:997-1002

29. Giannoudis PV, Grotz MR, Tzioupis C, Dinopoulos H, Wells GE, Bouamra O, Lecky F (2007) Prevalence of pelvic fractures, associated injuries, and mortality: the United Kingdom perspective. J Trauma 63:875-883. https://doi.org/10.1097/01.ta.0000242259 .67486 .15

30. Pohlemann T, Tscherne H, Baumgartel F, Egbers HJ, Euler E, Maurer F, Fell M, Mayr E, Quirini WW, Schlickewei W, Weinberg A 
(1996) Pelvic fractures: epidemiology, therapy and long-term outcome. Overview of the multicenter study of the pelvis study group. Der Unfallchirurg 99:160-167

31. Gabbe BJ, de Steiger R, Esser M, Bucknill A, Russ MK, Cameron PA (2011) Predictors of mortality following severe pelvic ring fracture: results of a population-based study. Injury 42:985-991. https ://doi.org/10.1016/j.injury.2011.06.003
32. Morris SA, Loveridge J, Smart DK, Ward AJ, Chesser TJ (2012) Is fixation failure after plate fixation of the symphysis pubis clinically important? Clin Orthop Relat Res 470:2154-2160. https://doi. org/10.1007/s11999-012-2427-z 